\title{
DIGITALCOMMONS
}

$@$ WAYNESTATE-

Wayne State University

$1-1-2014$

\section{Judicial Authority in WTO Law: A Commentary on the Appellate Body's Decision in China-Rare Earths}

Julia Ya Qin

Wayne State University

\section{Recommended Citation}

Qin, Julia Ya. Judicial Authority in WTO Law: A Commentary on the Appellate Body's Decision in China-Rare Earths. 13 Chinese J. Int'l L. 639 (2014)

Available at: https://digitalcommons.wayne.edu/lawfrp/254 


\section{Editorial Comments}

\section{Judicial Authority in WTO Law: A Commentary on the Appellate Body's Decision in China-Rare Earths}

Julia Ya Qin*

1. The recent decision of the World Trade Organization's Appellate Body (AB) in China-Rare Earths ${ }^{1}$ has put an end to the high-profile disputes over China's policies to restrict the exportation of rare earths and other raw materials. China has lost the case, and is expected to remove the export restrictions in compliance with the WTO decision. Despite resolution of the disputes, however, the AB's decision has failed to clarify a systemic issue at the heart of the disputes, namely, the relationship between the WTO agreements on one hand, and an accession protocol whose provisions modify the application of the WTO agreements to the acceded Member, on the other. In addition, the $A B$ chose not to address the dissenting opinion from the Panel below and the views of several third parties that disagreed with the AB's prior ruling on the same legal issue in China-Raw Materials, ${ }^{2}$ thereby forgoing the opportunity to reexamine and possibly reverse its controversial ruling. The AB's decision thus raises some serious issues about judicial authority in WTO law.

\section{Background}

2. The Rare Earths case was brought by the United States, the European Union and Japan in March 2012, challenging China's use of export duties and quotas on rare earths, tungsten and molybdenum as inconsistent with WTO law. The complainants

* $\quad$ Professor of Law, Wayne State University Law School, U.S.A.; Tsinghua University School of Law, China; Editor of this Journal.

1 AB Reports, China-Rare Earths, WT/DS431, 432, 433/AB/R (7 August 2014).

2 AB Reports, China-Raw Materials, WT/DS394, 395, 398/AB/R (30 January 2012). 
charged that China's measures breached its commitments to eliminate export duties under Paragraph 11.3 of China's Accession Protocol, and violated Article XI of the General Agreement on Tariffs and Trade (GATT) which prohibits all quantitative restrictions on exports. In defense, China invoked the general exceptions under GATT Article XX(b) and (g), which excuses measures necessary to protect public health or relating to the conservation of exhaustible natural resources.

3. China is the world's largest producer and exporter of rare earths, a key input for many high-tech and strategic products. Production of rare earths is highly polluting. For years, China mined and processed the minerals with little regard for environmental protection, resulting in massive pollution in the mining regions as well as rapid depletion of rare-earths resources. Today, China supplies $95 \%$ of the global demand, even though it has only $30 \%$ of the world's known reserves. Desiring to conserve natural resources and strengthen environmental protection, but not to hinder development of domestic downstream industries, the government resorted to export restrictions so as to reduce foreign consumption. This policy, however, is inconsistent with the WTO rulings in Raw Materials, which became effective in February 2012, requiring China to treat foreign and domestic users evenhandedly in the distribution of its raw materials. (It should be noted that WTO law generally allows a Member to restrict exports by customs duties; but since China agreed to eliminate export duties in its Accession Protocol, it has forgone this right. ${ }^{3}$ )

4. The main issues in Rare Earths are almost identical to those in Raw Materials. As in Raw Materials, the key question concerning export quotas was whether China's measures met the requirements of Article XX, an evidentiary matter mostly. The Panel answered the question in the negative, and the Panel's ruling was upheld by the Appellate Body on appeal. Also as in Raw Materials, the key question concerning export duties was whether China may invoke GATT Article XX to defend a breach of its commitment under Paragraph 11.3 of its Accession Protocol. Following the AB's ruling in Raw Materials, the majority of the Panel found that GATT Article XX is not applicable to Paragraph 11.3 of China's Accession Protocol. But one Panelist disagreed and filed a dissenting opinion on the issue. The Panel ultimately concluded that, even assuming GATT Article XX was available to Paragraph 11.3, China did not demonstrate that its use of export duties met the requirements of Article XX.

5. On appeal, the central issue for China was the applicability of GATT Article XX to Paragraph 11.3 of its Accession Protocol. This is a pure legal issue that had already been decided once by the Appellate Body in Raw Materials. Although in theory WTO dispute settlemet rulings are binding only on the parties to a particular dispute, in practice the Appellate Body has treated its decisions as de facto binding precedents. Absent

3 See Julia Ya Qin, The Predicament of China's "WTO-Plus" Obligation to Eliminate Export Duties: A Commentary on the China-Raw Materials Case, 11 Chinese JIL (2012) 237-246. 
"cogent reason", the AB held, "an adjudicatory body will resolve the same legal question in the same way in a subsequent case". ${ }^{4}$ Reluctant to challenge a precedent directly, China did not appeal the majority Panel's finding. Instead, it sought to clarify the systemic relationship between the WTO agreements and the provisions of its Accession Protocol generally. To that end, China advanced a number of new arguments purporting to show that GATT Article XX is applicable to Paragraph 11.3 of its Accession Protocol. All of China's arguments were rejected by the Appellate Body.

\section{Disagreement with the Appellate Body's Ruling}

6. In contrast with China's circumspect approach, the dissenting Panelist and several third parties participating in the case argued plainly that GATT Article XX should be applicable to Paragraph 11.3 of China's Accession Protocol, thus openly disagreeing with the Appellate Body's decision. This is a remarkable fact given the de facto binding status of the $A B$ rulings.

What is also remarkable is how opinions on this issue had shifted within a relatively short period of time. When China invoked Article XX to defend its breach of Paragraph 11.3 in Raw Materials, the panel was unanimously opposed, and none of the third parties supported China's position. Barely two years later, the Rare Earths proceedings witnessed one Panelist and several third parties siding with China on the issue. At the appellate stage, four out of the eight third parties that expressed views on this issue (Argentina, Brazil, Columbia, and Russia) supported the position of China and of the dissenting Panelist, with a fifth (South Korea) advocating the need to examine the record of China's accession negotiations in order to answer the question properly. ${ }^{5}$ Thus, the majority of the third parties that spoke on the issue favored a reconsideration of AB's prior ruling.

7. This major shift of opinion among the participating Members, however, is not surprising. As previously commented in the pages of this Journal, ${ }^{6}$ the AB's ruling that GATT Article XX is not applicable to Paragraph 11.3 of China's Accession Protocol is highly problematic. Paragraph 11.3 prescribes China's obligation to eliminate export duties, which is a "GATT-plus" obligation since the GATT explicitly permits a Member to levy export duties. ${ }^{7}$ China's Accession Protocol does not contain any

4 AB Report, US-Stainless Steel from Mexico, WT/DS344/AB/R (30 April 2008), para. 160.

5 See AB Reports, China-Rare Earths, paras. 2.218-2.243. There were altogether 16 third parties participating in Rare Earths, and eight of them (Australia, India, Indonesia, Oman, Peru, Taiwan, Turkey, and Vietnam) did not express any view on the issue. The three countries opposing China's position were Canada, Norway and Saudi Arabia.

6 Supra note 3.

7 GATT Article XI:1. 
general exceptions of its own, and is silent as to whether the general exceptions of GATT Article XX is available to China's GATT-plus obligations. The question confronting the WTO judges, therefore, was how to interpret this silence. Instead of examining the inherent relationship between China's export duty obligations and the GATT provisions, the $A B$ focused only on the express words of Paragraph 11.3 and selected provisions in the Working Party Report on China's accession, and reached the following conclusion (AB Reports, Raw Materials, para. 306):

In the light of China's explicit commitment contained in Paragraph 11.3 to eliminate export duties and the lack of any textual reference to Article XX of the GATT 1994 in that provision, we see no basis to find that Article XX of the GATT 1994 is applicable to export duties found to be inconsistent with Paragraph 11.3.

The AB's narrow textualist interpretation is inconsistent with the customary rules of interpretation contained in Articles 31 and 32 of the Vienna Convention on the Law of Treaties (VCLT), which require a treaty interpreter to take into account broad contexts of the treaty and in the light of its object and purpose when interpreting specific terms of the treaty. The AB's interpretation is also inconsistent with the "holistic" approach that it has advocated for the interpretation of WTO provisions. ${ }^{8}$ Legally, the AB's ruling has created an irrational state of affairs in WTO law: while the most important obligations of the WTO, such as the most-favored-nation (MFN) and national treatment obligations, are all subject to public policy exceptions, a specific commercial commitment of China is not. Normatively, the AB's ruling stands for the undesirable position that, short of an explicit textual reference, a trade-liberalization obligation will trump the values of public health and environmental protection as a matter of WTO law.

8. The AB's ruling in Raw Materials has since met with much criticism. ${ }^{9}$ In Rare Earths, the dissenting Panelist authored a 20-paragraph separate opinion, analyzing comprehensively why Article XX and all other general exceptions of GATT should

8 See e.g., AB Report, EC-Chicken Cuts, WT/DS269, 286/AB/R (12 September 2005), para. 176 (stating that interpretation pursuant to the VCLT rules is "ultimately a holistic exercise").

9 E.g., Marco Bronckers \& Keith E. Maskus, China Raw Materials: A Controversial Step Towards Evenhanded Exploitation of Natural Resources, 13(2) World Trade Rev. 393 (2014); Matthew Kennedy, The Integration of Accession Protocols into the WTO Agreement, 47(1) J. World Trade 45 (2013); Elisa Baroncini, The Applicability of GATT Article XX to China's WTO Accession Protocol in the Appellate Body Report of the China-Raw Materials Case: suggestions for a different interpretive approach, 1(3-4) China-EU LJ 1 (2013); Bin Gu, Applicability of GATT Article XX in China-Raw Materials: A Clash within the WTO Agreement, 15(4) JIEL 1007 (2012); Qin, supra note 3. 
be automatically available to China's obligation under Paragraph $11.3 .{ }^{10}$ The dissenting Panelist and the several third parties in this case all recognized the inherent relationship between Paragraph 11.3 and the GATT provisions and emphasized the fundamental importance of the policy exceptions to the WTO system. Hence, they were of the view that, unless China explicitly waived its right to invoke the GATT policy exceptions, such exceptions should be available to China's obligation on export duties.

9. Regrettably, instead of seizing the opportunity to reexamine its previous decision, the Appellate Body saw "no reason to revisit" the ruling since China did not directly challenge it. (AB Reports, para. 5.65) It then conveniently ignored all the opposing arguments of the third parties, and dispensed with the entire opinion of the dissenting Panelist in a single footnote. ${ }^{11}$ That said, the Appellate Body apparently felt the need to recalibrate its approach in Raw Materials, as it stated:

[E]xpress textual references, or the lack thereof, to a covered agreement (such as the GATT 1994), a provision thereof (such as ... ArticleXX of the GATT 1994), or "the WTO Agreement" in general, are not dispositive in and of themselves. (AB Reports, para. 5.61, emphasis original)

This statement seems a far cry from the conclusion reached in Raw Materials quoted above. Having made this statement, however, the Appellate Body went on to claim that its ruling in Raw Materials was made "on the basis of a holistic analysis of all elements" (AB Reports, para. 5.63), thus effectively reaffirming its previous decision.

\section{Relationship between WTO Agreements and Accession Protocols}

10. Much of the confusion over the applicability of the GATT general exceptions to China's accession commitments stems from the lack of a clear understanding on the systemic relationship between China's Accession Protocol and the WTO agreements. In WTO practice, an accession protocol effectively serves two functions. One is to enable the applicant to accede to the Marrakesh Agreement Establishing the World Trade Organization (the WTO Agreement or the Marrakesh Agreement), to which the GATT and other trade agreements (collectively the "Multilateral Trade

10 Panel Reports, China-Rare Earths, WT/DS431, 432, 433/R (26 March 2014), paras. 7.118-7.138.

$11 \mathrm{AB}$ Reports, fn. 504. The note, which is to paragraph 5.68 that dismisses China's argument on the "intrinsic relationship" between specific provisions of its Accession Protocol and WTO provisions, reads as follows: "For these reasons, we also see no basis for the opinion of the dissenting panelist in these disputes that 'the defences provided in the GATT 1994 are automatically available to justify any GATT-related obligations, including border tariff-related obligations - unless a contrary intention is expressed by the acceding Member and WTO Members'. Indeed, the Appellate Body rejected arguments by China to this effect in China - Raw Materials". 
Agreements") are annexed. The other is to stipulate special terms that will apply to the relationship between the acceding country and other Members under the WTO Agreement. These special terms may elaborate, expand or modify the provisions of the Multilateral Trade Agreements. The accession protocol also declares that it is "an integral part of the WTO Agreement". It is unclear, however, how a special term of the accession protocol should be "integrated" into the WTO Agreement and what such integration may entail. In order to answer these questions, it is necessary to define the precise nature of the accession protocol and its relationship with the other agreements within the WTO legal framework. Because the accession documents contain little explanation on these foundational issues, the burden falls upon the treaty interpreter.

11. Thus far, the WTO judiciary has not clarified these foundational issues. In the several disputes involving China's Accession Protocol, the Appellate Body never discussed the precise nature or status of the protocol within the WTO treaty framework. As a result, it has not been able to properly define the relationship between the protocol provisions and the Multilateral Trade Agreements, which has led to problematic jurisprudence. ${ }^{12}$ In Rare Earths, China specifically requested the $\mathrm{AB}$ to clarify the systemic relationship between its Accession Protocol and the Multilateral Trade Agreements. In response, the Appellate Body conducted an "integrated assessment" on such relationship, and its conclusions are summarized below (AB Report, para. 5.57):

(a) Just as the Multilateral Trade Agreements are an integral part of the Marrakesh Agreement, and thereby, of the single package of WTO rights and obligations, so too is China's Accession Protocol an integral part of the same package.

(b) Like the approach to ascertaining the relationship among provisions of the Multilateral Trade Agreements, the specific relationship between the provisions of China's Accession Protocol, on the one hand, and the provisions of the Marrakesh Agreement and the Multilateral Trade Agreements, on the other hand, must be examined on a case-by-case basis through a proper interpretation of all relevant provisions. Neither obligations nor rights may be automatically transposed from one part of the legal framework into another.

(c) The question of whether the exceptions under the Multilateral Trade Agreements may be invoked to justify a breach of a particular protocol provision must also be answered on a case-by-case basis, and be ascertained through a

12 For instance, in China-Publications, WT/DS363/AB/R (21 December 2009), the $\mathrm{AB}$ overlooked the GATT provisions on state trading as the relevant treaty context for China's trading rights obligations under its Accession Protocol. Consequently, it misstated the way in which China's measures at issue may become "WTO-consistent", and erroneously declared a judicial standard for identifying the linkage between trade and traders while such linkage is manifestly established by the GATT provisions on state trading. For detailed analysis, see Julia Ya Qin, Pushing the Limits of Global Governance: Trading Rights, Censorship and WTO Jurisprudence - ACommentary on the China-Publication Case, 10 Chinese JIL (2011) 271, 295-299. 
thorough analysis of the relevant provisions on the basis of the customary rules of treaty interpretation, as well as the circumstances of each dispute.

In short, the Appellate Body was of the view that the relationship between China's Accession Protocol and the Multilateral Trade Agreements is not different from the relationship among the Multilateral Trade Agreements, since they are all "integral parts" of the WTO Agreement.

12. From this basic position, the Appellate Body dismissed all of China's arguments. China had contended that specific provisions of the accession protocol should be treated as integral parts of one of the Multilateral Trade Agreements, depending on the subject matter to which they "intrinsically relate". The AB rejected this argument on the grounds that China did not provide "a clear definition" of the "intrinsic relationship" test and that China's position "sits uncomfortably with our interpretation that rights and obligations cannot be automatically transposed from one part of the WTO legal framework to another". (AB Reports, para. 5.68) China also sought to differentiate its Accession Protocol from the Multilateral Trade Agreements, arguing that unlike the Multilateral Trade Agreements, its Accession Protocol is not a "self-contained agreement", since it does not include most of the important features that many of the Multilateral Trade Agreements possess, such as proper general exceptions, security exceptions, or a modification clause. The Appellate Body dismissed the term "selfcontained agreement" as not being "an apt descriptor" of any of the agreements contained in the integrated WTO framework. Within the single package of WTO rights and obligations, the Appellate Body opined, whether an instrument can be characterized as a self-contained agreement is of "limited relevance". (AB Reports, para. 570)

13. None of the above reasons offered by the Appellate Body is persuasive. The fact that an accession protocol is made an integral part of the WTO Agreement does not mean it must be integrated into the WTO legal framework in the same manner and on the same legal basis as the Multilateral Trade Agreements. Unlike the Multilateral Trade Agreements, which were concluded simultaneously to provide the substantive disciplines of the WTO, the accession protocol is by nature a legal instrument for the WTO to admit a new member. The purpose of the instrument is to integrate the acceding country into the WTO system so that it will abide by the substantive disciplines of the Multilateral Trade Agreements. In practice, this instrument has evolved into a substantive agreement that can prescribe additional rules applicable to the acceding country only. These country-specific rules may elaborate, expand or deviate from the provisions of the Multilateral Trade Agreements, and their scope and contents vary from country to country, depending on the outcome of particular accession negotiations. Regardless of its coverage, however, the accession protocol is not designed to provide a coherent new discipline. Instead, it is structured to address subjects across the entire spectrum of the WTO legal framework, all in the context of the particular conditions of the acceding country. In other words, the accession protocol provides special terms on the application of the Multilateral Trade Agreements to the acceding country. As such, the provisions of the protocol cannot be understood independently 
from the general disciplines of the Multilateral Trade Agreements. Given the particular nature, purpose and design of the accession protocol, its integration into the WTO Agreement can only be effectively achieved through the interaction between its specific provisions and the provisions of the Multilateral Trade Agreements that address the same subject matter.

14. Notably, China also submitted that its Accession Protocol is properly characterized as a "subsequent agreement" relating to the same subject matter in the sense of Article 30 of the Vienna Convention on the Law of Treaties. Accordingly, China contended, to the extent that specific provisions of its Accession Protocol conflict with the provisions of the Multilateral Trade Agreements, the protocol provisions will prevail to the extent of the conflict. Pointing to Paragraph 11.3 of its Accession Protocol and GATT Article XI:1, China explained that, pursuant to VCLT Article 30(3), GATT Article XI:1 has been modified by Paragraph 11.3, so that China can no longer freely impose export duties under Article XI:1. The Appellate Body again dismissed China's argument as not "comporting well" with its previously stated views. ${ }^{13}$ Without further explanation, the Appellate Body stated: "we do not consider Article 30(3) of the Vienna Convention to be apposite for understanding the relationship between the different components of this single package of rights and obligations, all of which form part of 'the same treaty' to which China acceded in 2001". (AB Reports, para. 5.70)

15. This summary dismissal of VCLT Article 30(3) as inapposite for understanding the relationship between the accession protocol and other components of the WTO Agreement may prove too hasty. VCLT Article 30, Application of Successive Treaties Relating to the Same Subject Matter, provides rules for determining the rights and obligations of state parties to successive treaties relating to the same subject matter. ${ }^{14}$ Pursuant

13 According to the $\mathrm{AB}$, China did not elaborate the concepts underlying its argument. AB Reports, para. 5.70.

14 Article 30 Application of Successive Treaties Relating to the Same Subject Matter:

(1) Subject to Article 103 of the Charter of the United Nations, the rights and obligations of States Parties to successive treaties relating to the same subject matter shall be determined in accordance with the following paragraphs.

(2) When a treaty specifies that it is subject to, or that it is not to be considered as incompatible with, an earlier or later treaty, the provisions of that other treaty prevail.

(3) When all the parties to the earlier treaty are parties also to the later treaty but the earlier treaty is not terminated or suspended in operation under article 59, the earlier treaty applies only to the extent that its provisions are compatible with those of the later treaty.

(4) When the parties to the later treaty do not include all the parties to the earlier one:

(a) as between States Parties to both treaties the same rule applies as in paragraph 3;

(b) as between a State party to both treaties and a State party to only one of the treaties, the treaty to which both States are parties governs their mutual rights and obligations. 
to Article 30(3), when all the parties to the earlier treaty are parties also to the later treaty but the earlier treaty is not terminated or suspended in operation, "the earlier treaty applies only to the extent that its provisions are compatible with those of the later treaty". This provision embodies the doctrine of lex posterior. It recognizes that the parties to a treaty may enter into a subsequent treaty that effectively modifies the earlier treaty. Article 30 covers not only the situation where the parties to the two treaties are identical, but also the situation where there are additional parties to the later treaty. Pursuant to Article 30(4)(b), when the parties to the later treaty do not include all the parties to the earlier one, "as between the States parties to both treaties and a State party to only one of the treaties, the treaty to which both States are parties governs their mutual rights and obligations". This provision is understood to cover both the situation where the additional party is only to the earlier treaty and the situation where the additional party is only to the later treaty. ${ }^{15}$

16. VCLT Article 30 applies to the relationship between the WTO Agreement (including the Multilateral Trade Agreements annexed thereto) and each subsequent agreement concluded within the WTO legal framework. An accession protocol is such a subsequent agreement - it is a treaty concluded between an acceding country and the WTO representing all incumbent Members, ${ }^{16}$ and its terms define the application of the WTO Agreement between the acceded Member and other Members. Since the accession protocol does not provide a general rule of conflict, the principles of VCLT Article 30(3) and (4) become applicable. Pursuant to those principles, as between the acceded Member and other Members, the protocol provisions shall prevail to the extent that they are inconsistent with the provisions of the WTO Agreement; but to the extent the provisions of the WTO Agreement are compatible with the protocol, the existing WTO provisions shall apply.

17. To illustrate, as China pointed out, Paragraph 11.3 of China's Accession Protocol is inconsistent with GATT Article XI, as it obligates China not to use export duties whereas GATT Article XI explicitly permits such use. Pursuant to VCLT Article 30(3), Paragraph 11.3 shall prevail over Article XI to the extent of such inconsistency. Thus, as

15 Ali Sadat-Akhavi, Methods of Resolving Conflicts between Treaties (Martinus Nijhoff, 2003), at 64; Malgosia Fitzmaurice \& Olufemi Elias, Contemporary Issues in the Law of Treaties (Eleven International Publishing, 2005), p. 322.

16 Technically, VCLT does not govern the WTO accession protocols, as it applies to treaties between States only. Rules governing agreements between a State and an international organization are set out in the Vienna Convention on the Law of Treaties between States and International Organizations or between International Organizations (21 March 1986) (VCLTIO), U.N. Doc. A/CONF.129/15. VCLTIO has not entered into force. Since VCLTIO contains nearly identical rules as VCLT, including the provisions on the application of successive treaties relating to the same subject matter in Article 30 of VCLTIO, and to the extent the VCLT rules have attained the status of customary international law, these rules apply to all subjects of international law, including international organizations. 
between China and other Members, GATT Article XI:1 has been effectively modified to the following effect:

Subject to Paragraph 11.3 of China's Accession Protocol, [n] prohibitions or restrictions other than duties, taxes or other charges, whether made effective through quotas, import or export licenses or other measures, shall be instituted or maintained by any Member on the importation of any product of the territory of any other Member or on the exportation or sale for export of any product destined for the territory of any other Member. (Modification in italics)

This modified version of Article XI:1 demonstrates how the provision of Paragraph 11.3 of China's Accession Protocol is effectively "integrated" into the WTO Agreement.

18. The modification of Article XI:1 by Paragraph 11.3, however, does not affect Article XX or any other exceptions available to Article XI:1. That is because the general exceptions of Article XX are not incompatible with the content of Paragraph 11.3, just as these exceptions are not incompatible with Article XI:1 or any other GATT obligations. ${ }^{17}$ Pursuant to VCLT Article 30(3), therefore, Article XX shall continue to apply to Article XI:1, as modified by Paragraph 11.3.

19. The above example shows that VCLT Article 30(3) not only is "apposite", but also is indispensable, for understanding the relationship between specific provisions of the accession protocol and those of the Multilateral Trade Agreements. In dismissing VCLT Article 30(3) as inapposite, the Appellate Body apparently overlooked the need to resolve inconsistencies between the provisions of the accession protocol and those of the Multilateral Trade Agreements. Without first identifying and resolving such inconsistencies, however, it is impossible to interpret the accession protocol and other components of the WTO Agreement as the "single package of rights and obligations" in a coherent manner.

20. In sum, when assessing the relationship between China's Accession Protocol and the Multilateral Trade Agreements, the Appellate Body focused only on their commonality of being "integral parts" of the WTO Agreement, but ignored the specific nature, purpose and design that make the protocol distinct from the Multilateral Trade Agreements. Having ignored the distinct characteristics of China's Accession Protocol, the Appellate Body was not to recognize that the protocol interacts with the Multilateral Trade Agreements in a very different manner from the interaction among the Multilateral Trade Agreements and that VCLT Article 30 contains the key to understanding the

17 As the dissenting Panelist in Rare Earths duly pointed out, the provisions of the GATT policy exceptions "strike a balance between the policy space governments enjoy to pursue legitimate objectives and their obligations under the GATT 1994". And "the fundamental importance of the flexibilities" provided in GATT Article XX is "incontrovertible", in light of the purpose and objective of the WTO embodied in the preamble of the WTO Agreement. Panel Reports, Rare Earths, para. 7.137. 
systemic relationship between the accession protocol and the WTO agreements. Consequently, the Appellate Body was unable to clarify such relationship or provide any meaningful guidance on how to analyze it, except to say that such relationship must be determined on "a case-by-case" basis.

\section{Legitimacy of WTO Judicial Authority: Need for Self-Correction}

21. The end result of the Rare Earths case was this: China has been finally denied the right to avail public policy exceptions to its obligations on export duties. The Appellate Body's rulings on this issue are difficult to defend, whether as a matter of treaty interpretation or WTO policy. The rulings may also have adverse implications for other acceded Members. As a party to the disputes, China is legally bound by these rulings. However, decisions of such problematic nature cannot help but tarnish the reputation of the WTO judicial authority.

22. A more important question arising from this case, therefore, is whether WTO judicial interpretations can be reexamined and modified. After all, the members of the Appellate Body are not infallible. The growing number of cases appealed, the increasing complexity of the issues involved (such as the novel challenge of interpreting the large gaps in China's Accession Protocol), and the very short timeline (90 days) imposed on the appellate review have all contributed to the chance of ill-considered decisions being made by the appellate judges.

23. By design, the system does have a mechanism to check the decisions of its judiciary. Pursuant to Article IX:2 of the WTO Agreement, it is the Ministerial Conference and the General Council that shall have "the exclusive authority to adopt interpretations" of the WTO provisions. In contrast, panels and the Appellate Body are charged with the task to "clarify the existing provisions" of the WTO agreements in accordance with the customary rules of treaty interpretation, and their findings and recommendations "cannot add to or diminish the rights and obligations provided in the covered agreements". ${ }^{18}$ Thus, in theory the Ministerial Conference or the General Council can overrule an $\mathrm{AB}$ ruling by issuing an authoritative interpretation of its own. In practice, however, the WTO "legislative" has never exercised this power. Given the current paralysis of its negotiation functions, the chance that the WTO legislative issues an "authoritative interpretation" is practically nonexistent. Against this political reality, the only hope that the system can rectify a judicial error lies in the willingness of the Appellate Body to self-correct.

24. Thus far, the Appellate Body has not shown any sign of the willingness to do so. In its 19-year history, the $\mathrm{AB}$ has never admitted committing any legal error. As noted above, to defend its problematic ruling in Raw Materials, the AB went so far as to claim 
that its ruling was based on "a holistic analysis of all elements", a claim that cannot be backed up by its report.

25. The unwillingness of the Appellate Body to admit that it may have made a mistake or has changed its mind on a given issue is baffling. As the de facto top judicial organ of the WTO, ${ }^{19}$ the Appellate Body has the power and authority not only to set a precedent, but also to change a precedent as it sees fit. Apparently, when stating that "absent cogent reason, an adjudicatory body will resolve the same legal question in the same way in a subsequent case" 20 - a statement made in the context of admonishing a panel for not following $\mathrm{AB}$ 's prior ruling on the same issue - the $\mathrm{AB}$ contemplated at least the possibility that it may one day depart from its previous decisions. Although what constitutes a "cogent reason" in the eye of the $A B$ remains to be seen, one would think the need to correct mistakes should count as one such reason.

26. The justification for treating the $\mathrm{AB}$ decisions as de facto binding precedents is the desirability of "consistency and stability" in the interpretation of WTO provisions, which the $\mathrm{AB}$ deemed as "essential" for promoting "security and predictability" in the WTO dispute settlement, as contemplated by Article 3.2 of the Dispute Settlement Understanding. ${ }^{21}$ Indeed, consistency of jurisprudence is valued in both municipal and international legal systems, as consistency of law is one of the basic requirements of the rule of law. ${ }^{22}$ Yet, consistency is not an end in itself. It is instead a means to ensure that the law will develop in a principled fashion so as to serve the ideal of the system. Thus, as Judge Tanaka of the International Court of Justice once noted: ${ }^{23}$

$[T]$ he requirement of the consistency of jurisprudence is never absolute. It cannot be maintained at the sacrifice of the requirements of justice and reason. The Court should not hesitate to overrule the precedents and should not be preoccupied with the authority of its past decisions. The formal authority of the Court's decision must not be maintained to the detriment of its substantive authority. Therefore, it is quite inevitable that, from the point of view of the conclusion or reasoning, the minority in one case should become the majority in another case of the same kind within a comparatively short space of time.

19 According to DSU article 17.14, an Appellate Body report "shall be adopted" by the Dispute Settlement Body (DSB) and "unconditionally accepted by the parties to the dispute unless the DSB decides by consensus not to adopt the Appellate Body report." The negative consensus requirement ensures that an $\mathrm{AB}$ report will always be adopted in practice.

20 Supra note 4.

21 Ibid., paras. $160-161$.

22 See Lon L. Fuller, The Morality of Law (rev. ed.1969), p. 39.

23 Barcelona Traction, Separate Opinion of Judge Tanaka, ICJ Reports 1964, at 63. 
27. In this regard, it is instructive to refer to the practice of the Supreme Court of the United States, whose decisions enjoy the formal status of stare decisis. During the period from 1810 to 1992, the Supreme Court in 204 cases overruled in whole or in part more than 300 of its own decisions. Of the 204 cases, 52 overruled the decisions made within the previous five years, including 25 that overruled the decisions entered within the previous two years or less. ${ }^{24}$ The Court has long held that stare decisis is "a principle of policy and not a mechanical formula of adherence to the latest decision". Helvering v. Hallock, 309 U.S. 106, 119 (1940). This is particularly true in constitutional cases "where correction through legislative action is practically impossible". Burnet v. Coronado Oil \& Gas Co., 285 U.S. 393, 407 (1932) (Brandeis, J., dissenting). In such cases, the sooner the Court can self-correct, the better it is for society, as there will be less time to create reliance on the erroneous positions. The basic attitude of the Court towards its own mistakes is reflected in these words of Justice Brandeis: "The Court bows to the lessons of experience and the force of better reasoning, recognizing that the process of trial and error, so fruitful in the physical sciences, is appropriate also in the judicial function". Ibid.

28. As in the US constitutional cases, correction of judicial interpretation through legislative action is practically impossible at the WTO. Under such circumstances, like the US Supreme Court, the WTO Appellate Body has the institutional responsibility to engage in self-correction and to do so when the first opportunity presents itself. Having decided more than one hundred cases in 19 years, the Appellate Body is well positioned to acknowledge and rectify past mistakes. It is one thing to let its jurisprudence gradually evolve along an intelligible path. It is quite another to allow major interpretive errors stay uncorrected and become part of the WTO acquis. The willingness of the Appellate Body to self-correct is essential for maintaining its substantive authority, on which also rests the legitimacy of the WTO dispute settlement system.

24 Source: U.S. Government Printing Office, Supreme Court Decisions Overruled by Subsequent Decision, Constitution of the United States of America: Analysis, and Interpretation - 1992 Edition, at www.gpo.gov/fdsys/pkg/GPO-CONAN-1992/ content-detail.html. 